\title{
THE ANALYSIS OF POLITENESS IN HARRY POTTER CHAPTER 1 MOVIE
}

\author{
Anisa Setyawati ${ }^{1}$, Silpia Rahayu ${ }^{2}$ \\ ${ }^{1}$ IKIP Siliwangi \\ ${ }^{2}$ IKIP Siliwangi \\ ${ }^{1}$ anisasetyawatii11@gmail.com, ${ }^{2}$ silpiarahayu@ikipsiliwangi.ac.id
}

\begin{abstract}
Nowadays, movie is a media which has a biggest impact for the people. With movie people can learn about language. Language is procedure by human for communication with other people. Pragmatics is the strategies to analyze what the purposes of the utterance understanding, in pragmatics there have politeness to known how people express their negative and positive face. When people approximately impressive that threatens an additional face, it is shows how a face threatening act's (FTA's). When people talk with the other they apply positive and negative face in communication to save threatening acts. This article examines is how the analysis of politeness in Harry Potter Chapter 1 Movie. The author tries to analyze negative face, positive face on dialogue in this movie. Politeness strategies can be finds from face threat and how the speakers produce the words and gesture to communicate between actor in the characters. This research is observes by the author, because the subject on this research are movie to known how the actor and actress used their face in the dialogue of it. The result in this research aims it is essential for language learners study about politeness principles in instruction to increase a good communication.
\end{abstract}

Keywords: Face Threatening Act's, Negative and Positive Face, Movie, Politeness

\section{INTRODUCTION}

Linguistics is a study about language, how the function and how the languages use to put together and make a meaning when people using language to communication with people. In language we should learn because language is not instinct. Language as tool for human communication, how people arrange the word and make a meaning to understand what people are saying. Language styling is referred to language which has been mixed with stylistic elements, especially a figure of speechor language style (Rahayu and Parmawati, 2020). (Febtrina, 2019) Stated when we study about language, not only efforts on the basic aspect but how usually the context of the language more uses in communication. It means that the language is automatically produced by human to communicating with every people.

Using language in communication is a part of pragmatics study. Pragmatics is in what way the language in use of the speakers meaning and the listeners interpretation by the contextual meaning. Pragmatics also talked about the implication of expressions. According to (Siddiqui, 2018) pragmatics contracts not only with the significance of a given sentence but also, it goes necessarily with a relative what to the hidden meaning of the utterance. In generally pragmatics telling about study what the meaning that reffering to the context in apply linguistics and as the aspect of social achievement and believed.

Politeness is to honor people as a polite communication (Mahmud, 2019). When people make conversation they used language to build the communication, in communication people have to consider the politeness principle. Politeness principle is speaker strategies to maintain responsiveness with the hearer and self-image. People use polite in their conversations or 
interaction to take care the social interaction with people by face and good language. (Leech, 1983) as cited in (Mansoor, 2018) Stated politeness principle proposes that every single has to maximize the expression of polite beliefs, minimize the expression of impolite beliefs.

Face Threatening Act's (FTA's) is act to express the face by people to polite the conversation by saving the act. (J \& Tanto, 2018) Stated FTA is the act an utterance forces their determination on the hearers, and then possibly threatens in the hearers face. Beside, (Brown \& Levinson, 1987) as cited in (Nuraeni \& Wibowo, 2018) stated there are two kinds in FTA's can happened to the speaker, there is 1) affrontthe utterance negative face and 2) straight damage utterance positive face.In our daily conversation with other people we always used FTA's to threaten our face and also our face saving act's to show good face in self-image. Face Saving Act's (FSA's) mentions to conserve a good self-image (Angginie et al., 2019).

\section{Positive Politeness and Negative Politeness}

In communication with the others, people using polite forreflection and fondness. Using politeness strategy in daily conversation it can save face of the hearer. There are two kinds politeness can be analyzed:

1. Positive Politeness

(Wardaugh, 2006) as cited in (Kamsali, 2017) Stated differentiates of indications to move to completeharmony thru presents of friendship, the use to salutations, and informal language use: we deal with others as friends and partners, do not impose on them, and by no meansthreaten their face.

2. Negative Politeness

(Yetty, 2018) Stated the face the simpleentitlement to space, personal conserves, right to non-distraction, and also face to freedom of accomplishment, freedom to obligation.

Based on explanation above, in positive politeness is a face to keep relation and polite the conversation, and then negative politeness is the face when utterance not polite the conversation. Besides, when people used they own face in positive or negative politeness based on their polite to who and why they using that face.

\section{Face Threatening-Act's (FTA's)}

According to (Cutting, 2008) as cited in (Pramesti et al., 2019) people have to heading and show responsiveness of the face, the public self-image, the intellect of self of the people we talk in command to arrive into social relationship. It means that Face Threatening-Act's is the utterance face and the hearer face in act for save the polite in communication and people might threaten also in self-image of the face. In FTA's there are two faces:

1. Positive Face

(Nuraeni \& Wibowo, 2018) Stated negative FTA's is the acts in that openly for the hearer thru show the utterance ensures in not expect to escape obstructing hearer freedom of the action, for example: in orders, to requests, give the suggestion, telling agreements, make promises, and compliments.

2. Negative Face

(Nuraeni \& Wibowo, 2018) Stated positive FTA's is the acts of that threaten positiveface need, this is showed by that the utteranceensures not attention about hearer feelings and wants, for example: criticism, telling disagreement, rejecter, disrespect, appearance of ferocious, and taking of bad news.

It means, in positive of face is a threatened which involved expressing negatively appraising the hearer positive face. But face of negative is an expression personal disinterest of the hearer. 


\section{Movie}

Film is recommended to watch by people, in this era most of people to watching movie because they are like a movie because movie is a media can make audience comfortable and then to forget their bored, depressed, and spending of time with their family. Based on the actor of 'Jack Nicholsen', that what the motive of why every people like to watch movies is because the movie delivers to entertainment, given inspiration and hope, also distress, then movie also takes viewers to the spaces they has not ever visited, the movie couriers a common of thing, irrespective of the differences (Kurniasih et al., 2018). Not only to entertain, movie also can be as a tool for people who watched as a media to learn about the language of the movie, and practice with their skills of language in speaking, reading the subtitle or face in the character and expression, listening the conversation, and got more vocabularies.

Thus, in the explanation above the writers try to analyze of positive face too negative face in Harry Potter Chapter 1 Movie. How the actor and actress using expression and intonation in the conversation and show the Face Threatening Act's also Face Saving Act's in the dialogue. It means we should know politeness strategy arranged it. In this research focused on analyze the positive face, negative face on the actors and actress in Harry Potter Movie.

\section{METHOD}

This research will find make descriptive qualitative method to perceive the dialogue from actor and actress in Harry Potter Chapter 1 Movie. Descriptive qualitative is measured proper to order and finding information related to the employment of technique, media, method, and process (Nunun, 1992) as cited in (Apsari, 2018). The technique of this research is watched a movie to see negative and positive politeness in characteristics of the actor and actress of the movie.

The instrument in this research is observes by the writers, because the subject on this study are movie. The research analyze the data in interpretation of politeness that using in characters of the actor and actress. The data was collected from Harry Potter Chapter 1 Movie. The writers watch Harry Potter Movie in this research to find politeness of the movie, from the dialogue based on scenes to analyze the politeness principles on FTA's, the positive, and negative face founded on the expressions from the actor and actress. To find the data the writers take from three scenes in this movie for analyze scene by scene with the random way.

\section{RESULTS AND DISCUSSION}

\section{Results}

The result in this research will findings the politeness in the face threat of character on Harry Potter Movie actors and actress on the dialogue (Jesus, 2020)

1. Negative Face

2. Positive Face

Scene 1

Dialogue

Petunia : : "Get up, Up (knock and sighs) Now!!"

Dudly : "Cousin, wake up! We are will visit to the zoo"

Petunia : "Oh here he comes the birthday boy!!"

Vernon : "Happy Birthday to my boy"

Petunia : "Why don't you cook the breakfast, and don't try to burn anything!"

Harry : "Yes, Aunt Petunia"

Petunia : "I just want everything will be a good for my dudley's special day" 
(a)

Vernon

Harry

Dudley

Vernon

Dudley

Vernon

Dudley

Petunia

Context

Analysis

\section{Scene 2}

Dialogue

Harry

Vernon

Hagrid

Vernon

Petunia

Hagrid

All

Hagrid

Dudley

Harry

Hagrid

Harry

Hagrid

Harry

Hagrid

Harry

Hagrid was learned it all?"

$\begin{array}{ll}\text { Harry } & \text { :"Wait, learnt what?" } \\ \text { Hagrid } & \text { :"You are a wizard, Harry." } \\ \text { Harry } & \text { : "I-I'm a what?" }\end{array}$

: "Yes, uncle Vernon."

: "How many are there?"

: "I counted them there are 36 " make a plan for going the zoo. to Harry.

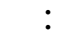

: "Ahh! Who is there?" and entering!"

: "Ohhhh"

: "Ahhhh!"

: "I-I'm not Harry."

: "I-I am Harry."

: "Sorry, I don't know about that"

: "Hurry up, come on cousin! And bring to my coffee"

: "What? 36?!! But last year.. last year I got more and it's 37!!"

: "Well, yes, several of them are relatively a bit more bigger than last year"

: "I really don't care how more big they are!"

: "Now, this is what we will going to do, when we go out we are going to buy two new presents for you! How is that pumpkin"

: This scene is doing in Harry Potter's house in the morning. Harry Potter is waking up by his aunt with the bad way, and his cousin continue to disturbing him with walked above the room. After that, Harry makes some breakfast for Vernon, Petunia, and Dudley. They have talking about Dudley's birthday and

: The utterance that used by the actor (Vernon, Petunia, and Dudley) almost all of them used the negative politeness when they talk with Harry. The speaker (Petunia) using that strategy on this dialogue, "I want all to be perfect for my Dudley's special day" because the speaker try to make intended meaning badly

: "Let's make a wish Harry" (He blows)

: "Oh, sorry about that" (He puts the door and back up again)

: "I demand that you just go out right now, sir! And then you are was breaking

: "Dry up, Dursley, you are great prune (the gun fires)"

: (Sees Dudley) "Mind, Harry. I have not seen you, too long since you was just a baby, however you are a little bit more alongside on than I might have expected. Particularly around the middle!"

: "Oh well, yes, in fact you are! Got one thing for you. Fraid I would have sat on it at some point. I imagine that it'll style fine simply identical. Ahh, Baked it myself (Hands Harry the cake) Words and everyone Heh"

: "Thank you!" (Opens cake, and that reads: Happy Birthday Harry)

: "It's not raguler that's your young man was turns eleven, now is it?"

: (Puts cake down) "Emmm pardon me, who are you?"

: "Rubeus Hagrid, I am a keeper of the keys, and also grounds at the Hogwarts. Course, you would grasp all regarding Hogwarts?"

: "No? Blimey, Harry, you didn't ever surprise whereever your mother and father 
Harry : "A wizard and a thumping sensible one of that, I had wager. And once you sequence up a touch"

Harry : "No, you have made a mistake. I can't be..a-a wizard. So I think, I'm just... Harry. Just one Harry"

Hagrid : "Well, Just a Harry, did you ever build something happen? Something you could not justify once when you angry with something or scared too? (Harry softens his expression)"

Dudley : : (whimpers)

Harry : : "Dear, Mr. Potter. We have a tendency to are happy to say to you that you just are accepted at Hogwarts' School of Witchcraft and Wizardry!"

Vernon : "Hell not be going! We have a tendency to swore after we was take him in the wed place an end to the present rubbish!"

Harry : "You knew?? You knew right it's along and you not to told me?"

Petunia : "Of course We have a tendency to knew. However may you not be? My excellent sister being who she was. Oh, my mother and father were therefor proud the day she got her letter. We have a witch in this family. Isn't it wonderful? I use to be the sole one to envision her intended for what she was, it's so freak! And finally she was met that a Potter, and you're born, also that I knew you had same like them, even as strange, just as...abnormal. After that, if you request, she went, and she got herself to blown up! And that we gain landed together with you."

Harry : "Blown up? But you told me if my parents was died in an exceedingly automotive crash!"

Hagrid : "A automotive crash? What a car crash killed James and Lily Potter?"

Petunia : "We had to inform him one thing"

Hagrid : "It's an cruelty! It is a scandal!"

Vernon : :"He will not be going!"

Hagrid : "Oh, and that I suppose an excellent Muggle like yourself about to stoped him, it's you?"

Harry : : "Muggle?"

Hagrid : "Non magic folk. This boy's had his name down ever since he was born! He is about to the best school of witchcraft and wizardry in the world, and he'll be underneat the best headmaster Hogwarts' has ever seen: Albus Dumbledore."

Vernon : "I won't pay for some crackpot old fool to teach him magic tricks!"

Hagrid : (Whips out umbrella and points it at Vernon) "Never insult Albus Dumbledore in front of me."

Dudley : : Ahh!

All

Harry

Hagrid : : "Oh, um, I'd give you appreciate if you didn't tell anyone at Hogwarts tell about that. Properly speaking, I'm not allowed to try and do magic."

Harry : (Nods) "Sure"

Hagrid : (checks a clock) "Oh, we are a touch behind the schedule. Best be off, unless you had rather stay, of course?"

Context : The day was changing, Harry draw the cake on the floor for his self to celebrate on his birthday, but Hagrid come with breaking the door to give the cake and talking about the truth about Harry.

Analysis : The utterance from Hagrid to Harry is always in positive politeness. But, Hagrid used in negative politeness when he speak with other. And Vernon, Petunia, and Dudley always use negative politeness by both of them. Harry used positive 
politeness to all of them. Harry always use in positive politeness because he try to make a self image for himself.

Scene 3

Dialogue :

Mrs. Weasley : "Fred, you are next"

George : "I am Fred, he's not Fred!"

Fred : "Honestly, woman, you called yourself our mother?!"

Mrs. Weasley : "Oh, I'm sorry, George."

Fred : "I'm only joking mom. I am Fred" (then fred runs through in the wall, also followed by his the twin brothers)

Harry : "Excuse me Mrs! C-could you explaind to me how to"

Mrs. Weasley : "Ohh, How to get on this platform? Of course, don't worry, dear. His neme's Ron's, he first time to Hogwarts too as well. (pan to the red haired boy is who smiles) then now, all you have got to do is walk just straight at the wall between the platforms in 9 and 10. If you nervouse the best way to do it at a bit of a run"

Ginny : : "Good luck"

Context : In the conversation above Harry try to takes a breath for runs at the wall. Also he make shuts his eyes and appear on the other side a magnificent station with a red train and bundles of the people. A whistle blows, and Harry breathing with the relief. After that Harry feel great because he do something unbelievable with a station wall.

Analysis : This scene show on how they got their first impression in a good way to met each other. Weasley's family use positive politeness to Harry because they always to make a good relation with every people.

\section{Discussion}

In this research was findings It can be seen if $100 \%$ Petunia, Dudley, and Vernon always using negative face in their conversation with Harry and other people, and Harry $100 \%$ using positive face in his conversation with anyone he met, Hagrid used 50\% positive face and 50\% negative face it's depend with whom he talked, then Mrs. Weasley $100 \%$ used positive face to hers parents and also to Harry. Harry as a main actor is not talking too much with the negative politeness. He just received many face in negative politeness from his uncle, aunty and his cousin. This is show that Harry is used Face Saving Act's that fear with the people's positive face lean to solidarity. And his uncle, aunty, and cousin do FSA's to Harry on negative face lean to appreciate they are antagonist.

\section{CONCLUSION}

After analyzing the data from movie of Harry Potter Chapter 1, the writers make a conclusion that politeness in this movie is based on the character, plot of a story, and climax necessary in this movie. Thus, that is a lot of positive politeness, and also negative politeness it is made contradictive. In using FTA's of politeness from discussion above, it can be conclude as follows: 1) In the first scene, Petunia, Dudley, and Vernon always used FTA's negative face to Harry's, also Vernon used negative face to his parents, when they made conversation no matter what the conversation about they using negative face on their dialogue 2)Then, on the second scene is Harry's birthday and he met with Hagrid, Harry look scared but he turn to polite the conversation using positive face, also Hagrid to Harry. But when Hagrid conversation with Petunia, Dudley, and Vernon he used negative face 3) In the last scene, Harry met with Mrs. 
Weasley. Even though they first meet, they are always using positive face in their conversation to polite the relation with each other.

\section{ACKNOWLEDGMENTS}

Alhamdulillahirabil'alamin, the researcher expressed the highest gratitude to Allah Subhanahuwata'ala for blessings, love, opportunity, health, and grace to completed this journal entitled The Analysis of Politeness in Harry Potter Chapter 1 Movie. In compiling this research, many people have provided motivation, advice, and support for the researchers.

The researcher appreciate and say thanks in advance first, the deepest appreciate given to beloved parents, for endless love, prayer, and support. Also thanks to Mrs. Silpia Rahayu, S.Pd., M.Hum. who was support and help to finished this research. The researcher fell very grateful to have some close friends who always support to finishing the research. This research is far from perfect, but it is expected to be useful not only for researchers, but also for readers. Hopefully the readers will understand with the explanation in this research.

\section{REFERENCES}

Angginie, V. A., Santika, T., \& El fauziah, U. N. (2019). Analysis About Politeness in "Barbie As the Princess and the Pauper Movie." PROJECT (Professional Journal of English Education), 2(3), 310. https://doi.org/10.22460/project.v2i3.p310-318

Apsari, Y. (2018). The Implementation of Project Based Learning in Coursebook Evaluation Classroom. Jurnal Ilmiah P2M STKIP Siliwangi P2M STKIP Siliwangi, 5(2), 1-6.

Febtrina, R. (2019). A Pragmatics Analysis of Politeness Strategies and Cooperation Principles in Beauty and the Beast Movie. 9(3), 6-11. https://doi.org/10.9790/1959-0903010611

J., \& Tanto, T. (2018). Request Strategies in Indonesian: an Analysis of Politeness Phenomena in Text Messages. Journal of Language and Literature, 18(2), 132-137. https://doi.org/10.24071/joll.2018.180204

Jesus. (2020). The Entire Script for ALL the Harry Potter Movies. Retrieved from Hogward is Here: https://www.hogwartsishere.com/library/book/739l/chapter/1/.

Kamsali, I. (2017). The Positive Politeness in Conversation performed by The Students of English Study Program of Timor University. Journal of Physical Chemistry B, 8(1), 2848. https://doi.org/10.1016/S0009-2614(00)00764-8

Kurniasih, N., Rizal, E., Winoto, Y., Sukaesih, S., Kurniawati, N., Sujito, S., Sudirman, A., Hasibuan, A., Daengs Gs, A., \& Saddhono, K. (2018). Retracted: Online Media as a Movie Reference. Journal of Physics: Conference Series, 1114(1). https://doi.org/10.1088/1742$6596 / 1114 / 1 / 012087$

Mahmud, M. (2019). The use of politeness strategies in the classroom context by English university students. Indonesian Journal of Applied Linguistics, 8(3), 597-606. https://doi.org/10.17509/ijal.v8i3.15258

Mansoor, I. K. (2018). Politeness : Linguistic Study. Internasional Journal In Social Sciences And Humanities. 8(4), 167-179.

Nuraeni, W., \& Wibowo, N. A. (2018). Analyzing Face Threatening Act in Whatsapp Group. PROJECT (Professional Journal of English Education), 1(4), 366. https://doi.org/10.22460/project.v1i4.p366-373

Pramesti, P. D. M. Y., Beratha, N. L. S., Budiarsa, M., \& Sudipa, I. N. (2019). The Role of Indonesian Caregivers' Nonverbal Elements and Face Threatening Acts toward the Aged. Theory and Practice in Language Studies, 9(9), 1243. 
https://doi.org/10.17507/tpls.0909.23

Rahayu, N. N., \& Parmawati, A. (2020). The Analysis Of Language Style And The Illocutionary Act Found In Teen Lit Novel "The Perfect Husband" Written By Indah Riyana. Project (Professional Journal Of English Education), 3(3), 408-413.

Siddiqui, A. (2018). "The principle features of English Pragmatics in applied linguistics." $\begin{array}{lllll}\text { Advances in Language and Literary Studies, } & 9(2),\end{array}$ https://doi.org/10.7575/aiac.alls.v.9n.2p.77

Yetty, '. (2018). Politeness Strategy on Social Interaction Used by Munanese. ELS Journal on Interdisciplinary Studies in Humanities, 1(1), 59. https://doi.org/10.34050/elsjish.v1i1.4043 